\title{
MEMBANGUN KOTA RAMAH ANAK DENGAN BUDAYA KOTA BERSERAMBI BACA
}

\author{
Susi Ratna Sari \\ Institut Agama Islam Negeri (IAIN) Bukittinggi \\ E-mail: ratnaguchie66@yahoo.co.id
}

\begin{abstract}
Abstrak: Kota merupakan sebuah rung publik yang memiliki rutinitas ekonomis dengan berbagai kegiatan corak dan dimensinya. Namun, kota juga mempunyai masalah sosial yang begitu kompleks, diantara masalah sosial itu terlihat dari masalah yang dihadapi oleh anak-anak di perkotaan. Masalah anak ini menjadi perhatian bagi kita semua, karena masalah anak jika dibiarkan bangsa ini akan mengalami krisis manusia yang berkualitas kedepannya. Terjadinya masalah anak di perkotaan ini, diantaranya disebabkan oleh minimnya fasilitas dan lembaga-lembaga yang memberdayakan dan mengayomi mereka. Untuk itu, salah satunya yang mendesak untuk dirancang di kota adalah serambi-serambi baca yang dapat diakses dan menampung anak-anak diperkotaan dengan aktivitas utamanya adalah membaca. Oleh sebab itu, kota masa depan perlu menumbuhkembangkan serambi-serambi baca tersebut, karena dengan adanya serambiserambi baca ini anak-anak diprediksikan bisa mengubah tradisi patologisnya ke tradisi yang berdaya guna dalam membangun masa depannya.
\end{abstract}

Kata Kunci: kota ramah anak, serambi baca, merubah tradisi patologis

\section{PENDAHULUAN}

Indonesia merupakan salah satu negara berkembang yang memiliki pertumbuhan kota sebagai sebuah satelit kehidupan sosial masyarakat yang begitu dinamik dan pesat. Kota hadir sebagai sebuah keharusan yang didesain untuk meningkatkan perekonomian dan akses social masyarakat terhadap pertumbuhan peradaban. Dengan harapan yang seperti itu maka bermunculan berbagai konsep kota di dunia termasuk pula di Indonesia. Namun, satu hal yang tidak bisa dipungkiri adalah kota harus tumbuh dan berkembang dengan budaya yang manusiawi, sebagai syarat mutlah kota masa depan. Kota yang memberikan kenyamanan dan kedamaian bagi siapa saja, termasuk kepada anak-anak sebagai generasi masa depan.

Kota sebagai satu ruang lingkup sosial dan sebagai tempat berkumpul dan bertemunya beragama komunitas dan budaya anak manusia dalam bergai lintas usia, ekonomi dan status serta gaya hidup sangat semestinya memberikan ruangan perhatian terhadap anak sebagai salah satu komunitas dari sebuah kota. Kegagalan sebuah kota memberikan ruang perhatian terhadap anak ternyata berimplikasi buruk terhadap kehidupan sosial, pertumbuhan, keselamatan dan masa depan anak. Dampak buruk ini dapat dilihat dari berbagai kekerasankekerasan yang diterima oleh anak-anak, mulai dari kekerasan seksual sampai pada kekerasan fisik, psikologis dan ekonomi.

Ketidakramahan kota terhadap anak-anak, diprediksikan sebagai salah satu yang membuat anak-anak Indonesia mengalami ketertinggalan, baik dari pendidikan, kesehatan dan kesejahteraan. Hal ini dapat dilihat dari data kekerasan terhadap anak di Indonesia yang dinyatakan dari tahun ke tahun jumlahnya terus meningkat. Masalah ini, harus menjadi perhatian semua kalangan mengingat anak-anak adalah 
penentu masa depan banga, jika hal ini dibiarkan tentu negara ini akan mengalami kebangkrutan atau krisis manusia yang berkualitas dimasa yang akan datang.

Oleh sebab itu pemerintah dan semua lampisan masyarakat harus berfikir dan menyusun program yang tepat guna untuk membangun masa depan anak-anak ini, salah satunya adalah melalui pembangunan kota yang ramah terhadap anak tersebut. Kota yang ramah terhadap anak, tidak hanya ditentukan oleh membangun fasilitas-fasilitas pembangunan yang memanjakan fisik anak-anak, tetapi mampu memberikan perlindungan dan kecerdasan terhadap anak.

Salah satu yang harus diperhitikan dalam membangun kota saat ini adalah membangun serambi baca yang penduli dengan anak-anak. Kota tidak hanya sebagai tempat syurga belanja tetapi juga harus memikirkan bagaimana anakanak bisa berdarmawisata dengan membaca buku, anak-anak bisa memanjakan dirinya dengan fasilitas serambi baca, sehingga anak-anak tidak hanya menjadi pembeli di kota dengan berbagai yang ditawarkan oleh penjual termasuk dengan mainan-mainan yang tidak mendidik.

Serambi baca yang ramah anak di perkotaan selain melindungi anak-anak dari kejahatan perkotaan, juga berpengaruh terhadap minat baca anak-anak Indonesia. Kehadiran serambi baca di perkotaan yang peduli terhadap anak selain melindungi anak-anak dari berbagai kejahatan dan budaya yang tidak baik juga akan berpengaruh terhadap peningkatan kualitas minat baca anak Indonesia. Terkait dengan masalah tersebut, tulisan ini berusaha untuk membas dan menganalisis secara ilmiah tentang membangun kota yang ramah anak melalui serambi baca yang peduli terhadap anak.

\section{PEMBAHASAN}

Berdasarkan banyaknya permasalahan anak yang dihadapi di negeri ini, maka perlu dilakukan upaya untuk mengatasi permasalahan itu. Diantara permasalahan yang dihadapi oleh anak-anak adalah sulitnya mendapatkan layanan dan fasilitas yang memadai untuk beraktivitas di kota. Bahkan di kota anak-anak sulit pula mendapatkan sarana dan fasilitas kota yang ramah terhadapnya, sehingga anak-anak di kota terjebak dengan menjadi pengamen, pemintapinta, eksploitasi dan berbagai kekerasan lainnya (Nitisastro, 2010: 391).

Dalam beberapa penelitian mengungkapkan kekerasan terjadi pada anak diperkotaan salah satunya disebabkan oleh anakanak tidak menemukan kota ramah terhadap kehadiran anak, konsep pembangun kota masih belum difikirkan ramah terhadap anak masih terjebak dengan stigma kota sebagai pusat perdagangan dan pusat belanja yang hanya memikirkan marketing pemasaran. Pada hal salah satu unsur yang hadir di kota itu adalah anak-anak.

Akhirnya perkotaan lupa membangun fasilitas sebagai wujud keramahannya terhadap anak. Ketidakpedulian kota terhadap anak, telah berdampak buruk terhadap anak, anak-anak kehilangan tempat bermain, tempat mengisi aktivitas keanak-anakkannya dan tempat belajar yang menyenangkan baginya. Kota hadir dengan kemegahannya tanpa memberikan rang untuk anak berekspresi dan beraktifitas.

Kota-kota yang tidak ramah anak ini memperpanjang masalah anak di perkotaan, diantara permasalahan anak yang akut di kota adalah Anak jalanan dan terlantar. Anak-anak jalanan ini hampir menjadi masalah anak di perkotaan di seluruh Indonesia, tidak saja di kota besar tetapi juga menjadi masalah di kota-kota kecil. Anak jalanan penuh dengan permasalahan, tidak hanya permasalahan dengan kekerasan kota 
tetapi juga permasalahan dengan keluarga, orang sekitar mereka, bahkan dengan pemerintah mereka juga mengalami permasalahan (Rizzana.dkk, 2014: 177). Dari tahun ke tahun anak jalanan jumlahnya selalu meningkat, mereka menjadi anak-anak terlantar dan tidak mendapatkan perhatian. Menurut data Kementerian Sosial terdapat 5,4 juta orang anak terlantar ini Indonesia ini yang tersebar diberbagai wilayah.

Aktivitas mereka hampir dipastikan dijalanan dan menggelendang, hidup dalam ketidakpastian karena tidak kembali kepada orang tua, tetapi menghabiskan waktu diantaranya dijalanan atau di emper-emperan, bahkan di bawah kolong jembatan. Biasanya mereka berkelompok-kelompok kadang-kadang mereka memakai simbol-simbol tertentu untuk penanda kelompok mereka. Di samping itu mereka pada umumnya putus sekolah atas berbagai alasan, ada alasan ekonomi keluarga, ada ketidak pedulian keluarga dan sebagainya. Mereka akhirnya memilih jalan pintas dengan menggelandang dan pada akhirnya aksi hidup mereka sering menjadi patologi sosial, karena anak-anak yang menggelandang di perkotaan rentang dengan narkoba, pelecehan seksual, kekerasan dan eksploitasi.

Diantara aktivitas anak-anak jalan yang menggelandang ini adalah meminta-minta baik dijalanan maupun ditempat-tempat keramaian, mengamen, menjaja koran dan bahkan mereka terlibat dengan pencopetan. Jika anak-anak ini dibiarkan menjadi peminta-minta tentu anakanak Indonesia memiliki mentalitas yang buruk dalam menghadapi masa depannya, sehingga bangsa ini mengalami kebangkrutan dalam menumbuhkembangkan manusia yang handal dan Idonesia akan terus mengalami krisis interpreneur sebagai salah satu penopang kesejahteraan bangsa. Menurut Ciputra (2008) Indonesia sekarang baru memiliki enterpeneur itu $0,08 \%$ dari penduduk Indonesia, pada hal syarat menjadi negara maju itu harus ada $2 \%$ dari jumlah penduduk yang berkiprah menjadi enterpreneur tersebut.

Di samping aktivitas-aktivitas mereka menjadi masalah sosial, ternyata anak-anak gelandangan di perkotaan juga rawan rawan eksploitasi, rawan sasaran kekerasan baik kekerasan seksual maupun kekerasan psikis. Bahkan diperkotaan anak-anak juga rawan dengan pekerja anak. Menurut laporan Statistical Information and Monitoring Programme on Child Labour (SIMPOC), mencatat bahwa tahun 2004 ditemukan 218 juta anak di dunia tereksploitasi. Dari jumlah yang tereksploitasi itu ditemukan 126 juta anak bekerja pada sektor yang sangat membahayakan kesehatan, serta 8 juta anak terjebak dalam kondisi yang sangat buruk yaitu mereka diperkejakan sebagai pekerja seksual, tergabung dengan konflik bersenjata. Pada tahun 2004, di Indonesia diperkirakan 1,4 juta anak berusia 10-14 tahun yang menjadi pekerja (Melani, dkk. 2014).

Tidak sedikit pula anak-anak diperkotaan terjerat oleh kasus penjualan orang, dimana anak-anak dijual untuk kepentingan ekonomi oleh sendikat-sendikat penjualan orang. Anakanak yang terjaring dalam kasus penjualan orang ternyata sering berujung pula pada kekerasan sesksual, mereka dijual kepada agent-agent penjualan orang yang bersendikat dengan germogermo. Permasalahan ini pun sudah menjadi pengetahuan umum sejak lama. Di Indonesia kasus penjualan orang ini cukup banyak, terutama dialami oleh anak-anak perempuan di bawa umur. Mereka diperdagangankan selain untuk tujuan bekerja juga tidak terlepas untuk komersialisasi pekerja seks. Hal ini terlihat dari hasil survei Komnas Perlindungan Anak, dimana dari 200-300 ribu perempuan yang dilacurkan, $30 \%$ adalah anak-anak perempuan. Menteri Pemberdayaan Perempuan pernah mempublikasikan data tersebut misalnya pada tahun 1999 sampai tahun 2000 di beberapa kota 
besar terrekam perdagangan anak perempuan sebagaimana terlihat pada tabel di bawah ini:

Tabel: Perdagangan Anak Perempuan Dari Beberapa Kota

\begin{tabular}{ccc}
\hline Kota & \multicolumn{2}{c}{ Tahun } \\
& 1999 & 2000 \\
Jakarta & 130 & 126 \\
Medan & 286 & 282 \\
Bandung & 161 & 157 \\
Padang & 151 & 147 \\
Surabaya & 313 & 309 \\
Bali & 133 & 129 \\
Ujung Pandang & 155 & 151 \\
Manado & 179 & 175 \\
Jumlah & 1.712 & 1.683 \\
Sumber Menag PP. Juni 2002 & \\
\hline
\end{tabular}

Meningkatnya angka perdagangan anak perempuan ini ditopang oleh sendikat yang profesional. Banyak anak-anak perempuan direkrut untuk diperdagangkan baik untuk pasaran dalam negeri maupun luar negeri. Anakanak yang diperdagangkan ini merupakan anakanak yang mengalami permasalahan di perkotaan. Selain dari itu anak-anak perkotaan juga sangat rawan terhadap kekerasan seksual. Data yang dipublikasi oleh Mensos misalnya menyebutkan pada tahun 2015 ini ditemukan ada 37 laporan terkait tinda pidana atas anak. Dari 37 kasus laporan tersebut 24 diantaranya merupakan kasus kekeraan seksual terhadap anak. Sementara itu Komisi Nasional Perlindungan Anak (Komnas PA) sebagai mana dilansir di media (Tempo. Com/akses.24/9) mencatat sudah terjadi 21,6 juta kasus kekerasan terhadap anak sepanjang 2010-2014. Data itu diambil dari 179 kota dan kabupaten di 34 provinsi di Indonesia. Dimana sekitar 58 persen atau 12,5 juta kasus merupakan kekerasan seksual terhadap anak. Dimana anak-anak dilacurkan terrnyata juga rawan terhadap penularan penakit, seperti HIV.

Anak-anak perkotaan juga sangat rentan terhadap narkoba. Mereka bisa menjadi pemakai atau bahkan menjadi korban daripada agen-agen pengedar narkoba, bahkan data terakhir menunjukkan bahwa di Indonesia ada 4,2 juta pemakai narkoba dan sebahagian besarnya adalah kalangan usia produktif termasuk anak-anak diusia sekolah. Bahkan belakangan ini, Indonesia disebut-sebut sebagai negara darurat narkoba. Oleh sebab itu, anak-anak Indonesia harus diselamatkan dari sepak terjang pergumulan dari peredaran pemakaian obat-obat terlarang tersebut.

Masalah lain yang dihadapi oleh anak-anak diperkotaan adalah, masalah seks bebas. Kementerian Kesehatan pernah mengeluarkan data tentang di beberapa kota besar 35,9\% remaja di kota besar sudah melakukan hubunagan seksual bebas (Kementerian Kesehatan. 2009). Hal ini menjukkan bahwa diperkotaan anak-anak atau remaja mengalami masalah dalam prilaku seksual. Bahkan anakanak juga menjadi korban yang dilacurkan.

Permasalahan-permasalahan anak di perkotaan itu, langsung atau tidak langsung jelas berpengaruh terhadap kualitas sumber daya manusia di negara ini. Kondisi ini dikuatirkan ikut menyumbang terhdap rendahnya kualitas hidup orang Indonesia. Jika dibandingkan dengan negara-negara tetangga, negara Indonesia memiliki kualitas hidup rendah dari Singapura dan Malaysia. Dari 187 negara yang di survei oleh UNDP Indonesia memiliki kualitas hidup di urutan 121. Sedangkan di ASEAN Indonesia menempati ranking 6, setelah Singapura, Brunei Darussalam, Malaysia, Thailand, Philipina dan Indonesia.

Melihat dari data-data dan fenomena tersebut, maka bangsa ini harus cepat berbenah dan pemerintah harus membuat terobosanterobosan untuk keluar dari ketertinggalan kualitas sumber daya manusia tersebut. Salah satu yang harus diupayakan oleh pemerintah adalah membangun anak-anak perkotaan supaya tidak terjebak dalam masa depan yang suram.

Perlu ada kebijakan yang signifikan untuk melindungi dan membangun kota yang ramah terhadap anak, sehingga mereka tumbuh dan 
berkembang sesuai dengan laju kota metropolis yang mempunyai sumber daya manusia yang berkualitas, tanpa meminggirkan satu sama lain. Sudah sangat diperlukan kehadiran kota tidak hanya sebagai lokusnya konsumerisme dan hedonisme, tetapi mendatangkan kota yang mampu memberikan perlindungan dan pengayaan nuraniah untuk siapa saja, terutama bagi anak-anak sebagai kelompok yang masyarakat dari perkotaan.

Nampaknya, yang perlu ada di perkotaan adalah menumbuhkembangkan serambi-serambi baca, serambi baca ini bisa saja hadir di mall, masjid, gereja, emperan toko dan seterusnya. Serambi baca merupakan semacam perpustakaan yang bisa diakses oleh anak-anak. Ia tidak mesti memiliki ruangan yang megah tetapi bagaimana di satu ruangan di sebuah bangunan ada tersedia satu fasilitas untuk ini, sehingga anak-anak dapat berkatifikas membaca dan bereskpresi sesuai dengan usianya.

Pemerintah perlu menggalakkan dan mengeluarkan kebijakan tentang ini, sehingga kota selain dipadati oleh perpelanjaan juga dilengkapi dengan ruang-ruang baca yang dapat membangun intelektual dan ekspresi anak-anak khususnya di perkotaan. Dengan adanya serambi baca ini, diprediksi anak-anak diperkotaan bisa meninggalkan tradisi-tradisi patologi sosialnya, karena semakin banyaknya masalah anak di perkotaan karena tidak munculnya gerakangerakan perubahan terhadap tradisi anak-anak di perkotaan tersebut, sementara faktor pendesak anak-anak perkotaan untuk melakukan tindakan atau prilaku ke arah patologi sosial itu sangat kompleks dan bergerak dengan cepat, sementara gerakan untuk mengatasnya statis.

Di sinilah pentingnya kehadiran serambi baca, ia memberikan ruang-ruang alternatif untuk anak-anak perkotaan terutama anak-anak perkotaan yang terlibat dengan patologi sosial, dimana serambi baca menawarkan alternatif kegiatan yang dapat meruah tradisi-tradisi mereka kedimensi yang fungsional. Di kota anak-anak harus menumukan kenyamanan dan keamanan ketika berada di kota, mereka terlindungi dan mendapatan masa fasilitas yang bisa membuat mereka bebas aktivitas sesuai dengan masanya.

Ada beberapa ciri kota yang ramah dan layak terhadap sebagaimana disebutkan dalam Peraturan Menteri Negara Pemberdayaan Perempuan dan Perlindungan Anak No.12 tahun 2011 diantaranya adalah tersedianya lembaga kesejahteraan sosial untuk anak. Lembaga tersebut mampu memberikan fasilitas bagi anak untuk mengembangkan diri dan kreativitasnya.

Salah satu yang paling didambakan dari lembaga itu adalah sebuah serambi baca kota yang bisa mengakomodasi anak-anak untuk tumbuh dan berkembang direalitas perkotaan. Di sinilah pentingnya kota masa depan membangun serambi baca ditengah-tengah hiruk pikuk kota. Dimana serambi baca memberikan sarana-sarana peningkatan minat baca terhadap anak dan sekligus sebagai lembaga belajar ditengah-tengah dinamisasi kota yang semakin dilahap oleh sistem kapitalis, hedonis dan individualistik.

Sudah saatnya kota-kota di Indonesia mempunyai agenda pembangunan kota dengan konsep tersebut, dimana dengan adanya serambi baca anak-anak tidak lagi melibatkan diri dengan kegiatan-kegiatan jalanan dan menelantarkan diri, tetapi bisa belajar dengan fasilitas yang tersedia, karena terjadinya permasalahan anak diperkotaan sebanranya dipengaruhi oleh tidak adanya lembaga dan ruangan yang representatif untuk anak, karena semua ruang di perkotaan selalu dihargai untuk kebutuhan dan kepentingan ekonomi. Pada hal kota dengan segala kompleksitasnya harus mempunyai ruang dan lembaga yang bisa memberikan perlindungan dan kenyamanan untuk anak, 


\section{7-200 | HARKAT: Media Komunikasi Islam Tentang Gender dan Anak, 11 (2), 2015}

sehingga anak tidak memperpanjang dereta menjadi anak jalanan dan terlantar.

Kehadiran serambi baca kota bisa dilakukan dengan berbabagai kebijakan dan keterlibatan berbagai kalangan tidak hanya tergantung pada pemerintah semata. Lembagalembaga non pemerintah pun, punya andil besar dalam mewujudkan lembaga yang bisa membangun anak-anak kota mencintai ilmu melalui fasilitas serambi baca tersebut. Misalnya, hotel-hotel bisa mengambil peran untuk ini dengan menyediakan serambi baca disalah satu sisinya atau masjid-masjid dan rumah ibadah bisa menyediakan pula serambi baca untuk anak-anak begitu pula dengan mall-mall harus menyedikan serambi baca itu, sehingga mall tidak hanya sebagai tempat belanja yang memikat dengan berbagai pesonanya.

Fungsi utama serambi baca ini adalah, anak-anak mudah mengakses ilmu pengetahuan sehingga mereka tidak menjadi anak terlantar yang menghabiskan waktu di jalan atau menongkrong di tempat-tempat yang rawan menciptakan mereka terlibat dalam berbagai masalah anak di perkotaan. Oleh sebab itu serambi baca tersebut harus menjadi konsep pembangunan perkotaan, sehingga di kota-kota tumbuh berkembang serambi-serambi baca yang bisa diakses oleh anak-anak untuk membangun masa depannya. Kehadiran serambi baca dapat berkontribusi dalam mengatasi berbagai problem yang dihadapi oleh anak-anak di perkotaan, diantaranya adalah:

1. Merubah tradisi jalanan ke tradisi baca

Sesungguhnya keterlibatan anak di jalanan tidak hanya diakibatkan oleh faktor ekonomi, tetapi juga diakibatkan oleh tidak adanya lembaga yang dapat menampung mereka untuk beraktivitas, tidak ada ruang-ruang yang dapat memfasilitasi mereka untuk berkativitas dan bereksprei, karena kota dibangun setiap jengkalnya dengan konsep pasar yang ekonomis dan hedonis, sehingga akhirnya jalanan menjadi pilihan tempat beraktivitas untuk berekspresi, pada hal kehadiran mereka sangat menganggu kenyamanan dan ketertiban. Selagi tidak ada tempat-tempat alternatif yang meberikan perlindungan dan kenyamanan bagi anak-anak yang memiliki masalah di perkotaan ini, maka aktivitas di jalanan adalah bentuk perlawanan bagi mereka terhadap ketidakpedulian kota terhadap masa depan mereka. Mengembara di jalan akan terus menjadi tradisi kehidupan mereka, sehingga dari ke hari deretan masalah mereka semakin panjang dan semakin kompleks.

Serambi baca ini, hadir menjadi pengubah tradisi mereka dari tradisi jalanan yang "keras" dengan mentalitas-mentalitas yang menganggu perkembangan anak kota yang menghadapi masalah menjadi tradisi baca yang dapat meningkatkan hidup anak jalanan dengan konsep belajar dan membaca. Melalui kegiatan belajar dan membaca ini mereka bisa merobah pola hidup serta cara pandangnya terhadap masa depan. Semula mereka tidak memiliki wawasan untuk kedepan, dengan membaca mereka memiliki wawasan kedepan untuk membangun hidup mereka. Serambi baca di perkotaan, tidak sekedar sebagai tempat buku ditumpuk-tumpuk tetapi ia hadir menjadi penerang di tengahtengah anak-anak kota yang tidak memiliki keberuntung disegi pendidikan, ekonomi dan perhatian orang tua.

Jika tradisi baca itu tumbuh dan berkembang, tentu minat baca anak-anak di negeri ini tidak lagi tertinggal dibandingkan dengan negara-negara lainnya. Menurut data UNESCO seperti yang diterbitkan di kompas.com (akses 24/9) menyebutkan minat baca anak Indonesia sangat rendah sekali 0,01 persen. Berarti dari 10.000 orang anak hanya satu yang memiliki minat baca. Anak-anak yang rendah minat baca ini berdampak terhadap rendahnya kualitas hidup, karena mereka tidak mengisi ruang-ruang yang berpotensi dalam dirinya dengan membaca tersebut. 
Anak-anak yang tidak terisi ruang-ruang yang potensialnya ini, menurut hasil penelitian Cullinan\&Bagert (Hanani, 2013:79) cendrung melahirkan tindakan radikal dan tidak mampu memberikan analisis atas realitas yang dihadapinya, sehingga ia hanya bertahan dalam realitas-realitas kepatologisannya. Oleh sebab itu, anak-nak jalan atau anak-anak yang bermasalah diperkotaan cenderung anarkis dan menyelesaikan masalah kehidupannya dengan cara kekerasan, bahkan mudah berkelahi, mudah melakukan tindakan kriminal dan seterunya.

2. Merubah tradisi kekerasan kepada tradisi keberdaban

Anak-anak di perkotaan hidup dalam situasi kerasan daya tawar sosial, ekonomi dan budaya kota, karena di kota orang berpacu persaiangan ekonomi yang ketat dan agak mengeyampingkan rasa persaudaraan. Oleh sebab itu, tidak heran anak-anak diperkotaan sering menjadi korban dari persaiangan-persaiang tersebut, sehingga anak-anak rawan menghadapi berbagai eksploitasi dan kekerasan. Untuk menghindari anak-anak dari situasi yang kurang memiliki keberadaban ini, maka diperkotaan harus mempunyai tempat yang meberadabankan anak-anak yang masih mempunyai masa depan yang panjang.

Berkaitan dengan itu, kehadiran serambi baca di tengah perkotaan sebagai sarana untuk merubah pola kekerasan kota kedimensi kota yang mempunyai peradaban. Anak-anak perkotaan pun bisa menikmati arti penting kota dalam hidup mereka. Di mana kota tidak hanya dimakanai sebagai tempat kompetitif ekonomi yang hanya memberikan kenikmatan bagi orang orang-orang tertentu, tetapi dengan serambi baca kota bisa menjadi pelindung konstruktif terhadap pemberadaban umat manusia. Secara langsung atau tidak langsung serambi baca mewujudkan situasi kota yang lebih beradab.

Dalam konteks ini, serambi baca menjadi alternatif untuk membangun peradaban kota yang manusiawi terhadap anak-anak. Perkotaan bisa membangun daya tawar peradaban yang manusiawi.. Dimana anak-anak bisa melakukan perubahan tradisi dari kekerasan kepada tradisi yang manusiawi dan berkeadaban. Perubahan tradisi ini bisa dilakukan dengan tindakan dan aksi yang bisa membangun kemanusiaan melalui pembangunan fasilitas-fasilitas yang memberadabkan. Jika upaya-upaya pemberadaban ini tidak dikontruksi di kota, maka kota akan membentangkan beragam masalah kemanusiaan dan kota tidak menjadi tempat yang nyaman bagi semua orang, tetapi menjadi tempat yang menindas kemanusiaan. Percayalah apa yang dikatakan oleh Giddens (2000;x) masalah itu melaju dengan kencang yang membawa manusia dalam berbagai perbenturan-perbenturan, tugas utama manusia sekarang adalah membangun benteng perbenturan itu. Maka dalam konteks ini, serambi baca sebagai sarana untuk menimalisir perbenturan-perbenturan tersebut.

3. Merubah tradisi ketidakberdayaan ke tradisi yang memberdayakan

Beragamnya masalah yang dihadapi oleh anak-anak di perkotaan, telah mendesain kondisi ketidakberdayaan dikalangan anak-anak tersebut. Mereka hidup dalam ketidakpastian karena masalah-masalah yang mereka hadapi tidak mendapat penyelesaian. Bahkan penyelesaiannya pun tidak dilakukan dengan pemberdayaan yang manusiawi, tetapi dilakukan dengan kekerasan, mereka ditangkap diuber-uber dan seterusnya.

Untuk menghindari pendekatan masalah yang seperti itu, maka diperlukan serambi baca sebagai pendekatan alternatif yang lebih manusiwi. Eksistensi serambi baca memberdayakan mereka dengan pendekatanpendekatan yang membangun reputasi kemanusiaan, sebab konsep ini hampir lupa belakangan diciptakan oleh kota-kota di Indonesia sehingga kota menghadapi berbagai masalah kemanusiaan. 
Kehadiran serambi baca di perkotaan, secara langsung atau tidak langsung menjadi salah satu sarana untuk menanggulangi anakanak diperkotaan mengalami masalah tersebut. Serambi baca bisa menjadi sarana pencerahan bagi anak-anak diperkotaan dan sekaligus menajadi ruang yang memberdayakan mereka dengan berbagai kegiatan yang berdayaguna.

Dengan demikian, anak-anak diperkotaan tidak mudah tereksploitasi, karena mereka mendapatkan perlindungan yang memberdayakan dari serambi baca. Selama ini bagi anak-anak yang mengalami permasalahan di perkotaan, menghabiskan waktunya di jalan yang kerab dengan kekerasan tetapi dengan adanya serambi baca mereka bisa menyisihkan waktunya di ruang yang bisa memberdayakan mereka melalui buku dan fasilitas serambi baca..

Serambi baca sebagai salah satu langkah untuk membangun kualitas anak-anak Indonesia, karena mereka terakomodasi dalam memecahkan masalah hidup mereka dengan ruang baca kota yang bisa mereka akses dengan mudah. Fasilitas kota yang seperti ini, jelas memberikan arti penting dalam mengubah mentalitas anak-anak kota yang mengalami masalah tersebut. Minimal akan terlihat dari cara mereka menghadapi dan menyelesaikan masalah dalam hidupnya, karena anak-anak yang membaca mempunyai kemampuan untuk menganalisis realita, dimana mereka akan memiliki cara bertindak, cara berkomunikasi dan berinteraksi dengan peradaban bukan dengan cara kekerasan (Cullinan\&Bagert, 1996).

Artinya, jika anak-anak perkotaan dibiarkan dengan ruang hampa pemberdayaan tentu masalah-masalah anak diperkotaan tidak akan berkurang, tetapi akan melaju jumlah permasalahannya sehingga kota tumbuh dengan generasi-generasi yang memiliki daya saing yang rendah, akhirnya kekuatan ekonomi bangsa ini semakin bertumpuk pada kelompok-kelompok tertentu saja.

\section{Menumbuh kembangkan Serambi Baca Kota}

Untuk menyelamatkan anak-anak perkotaan, maka lembaga-lembaga perlindungan anak harus tumbuh dan berkembang. Salah satu yang harus dikembangkan adalah serambiserambi baca kota yang bisa menjebatani anakanak perkotaan untuk belajar. Pemerintah harus mempunyai kebijakan untuk mendukung kehadiran serambi baca ini, sehingga kota tidak hanya tumbuh dan berkembang sebagai lalu lintas perdagangan dengan berbagai daya tawarnya tetapi juga mendesain kota dengan pertumbuhan fasilitas pemberdayaan yang bisa mendesain kualitas manusia sebagai penghuni kota.

Serambi baca dilaksanakan bisa berbasis masyarakat perkotaan, misalnya melalui kebijakan satu mall menyediakan satu ruangan untuk serambi baca, atau satu rumah ibadah di kota memiliki satu serambi baca, atau satu hotel harus mendesain satu tempat untuk serambi baca dan seterusnya, sehingga perkotaan tidak hanya dipadati oleh kemegahan-kemegahan yang pada satu sisi tidak memiliki kepedulian terhadap lingkungannya.

Kehadiran serambi baca ini secara langsung atau tidak langsung jelas membantu keterbatasan-keterbatasan sarana jangkauan perpustakaan di negeri ini, dimana jumlah perpustakaan itu pun jumlahnya sangat terbatas. Menurut Taryadi (Hanani, 2013; 84) di Indonesia rasionalitasnya satu perpusatakaan umum sekarang melayani 85 ribu penduduk Indonesia, tentu kondisi ini dirasakan sangat terbatas, tidak semua orang pula mudah untuk mengakasesnya.

Terkait dengan keterbatasan tersebut, maka serambi baca menjadi salah satu kebutuhan kota yang harus ditumbuh kembangkan dalam rangka membangun kualiatas anak-anak diperkotaan sehingga mereka tidak mudah terjebak ke dalam tindakan patologis sosial. Sudah saatnya pula pembangunan kota layak 
anak menekankan konsep kota berserambi baca ini, kota yang didesain gemar membaca dan mencintai buku dengan fasilitas serambi baca tersebut.

Pertumbuhan kota dengan serambiserambi baca ini diperediksikan akan membangun kota dengan peradaban, kota yang ramah terhadap kemanusiaan dan kota yang memberikan solusi terhadap pemecahan masalahmasalah yang dialami oleh anak-anak diperkotaan. Tradisi-tradisi patologis anak-anak diperkotaan akan beralih menjadi tradisi serambi baca yang memberdayakan kualitas manusia.

\section{PENUTUP}

Kota di Indonesia, dari waktu ke waktu mengalami perubahan yang begitu komplek dengan permasalahan yang beragam, salah satu permasalahan itu adalah terkait dengan permasalahan anak di perkotaan. Permasalahan anak itu dapat dilihat dari realitas yang muncul dari hari ke hari dengan menunjukkan realitas patologis sosial anak. Dimana anak-anak terhempas secara manusiawi dari kedigdayaan kota sebagai satelit ekonomi dan perdagangan.

Untuk menghindari masalah itu semakin komplek, maka perlu dilakukan kebijakan untuk membangun kota dengan serambi baca, kota yang mendesain sebagai sumber belajar yang mewadahi anak-anak perkotaan dengan buku dan faslitas yang bisa memberdayakan mereka, sehingga anak-anak di perkotaan tidak lagi menyeleasikan masalah hidupnya di jalan, di bawah kolong jembatan dan bahka tidak lagi mudah dieksploitasi dan dilacurkan. Serambi baca sudah sangat mendesak didesain di kota mengingat terbatasanya faslitas-faslitas kota yang memberdayakan anak-anak kota utuk menemukan jati diri dan kualitas hidupnya.

\section{DAFTAR PUSTAKA}

Ciputra. 2008. Menjadi Pengusaha Tanpa Modal. Yogyakarta. Sekolah Pascasarjana UGM.

Cullinan, B\&Bagert. 1996. Helping Your Child Learn to Read. Washington. Office of Education Research and Improvement. US.Dept. Edication.

Giddens, Anthony. 2000. The Third Way Jalan Ketiga Pembaruan Demokrasi Sosial. Jakarta. Gramedia Pustaka Utama.

Hanani, Silfia. 2013. Sosiologi Pendidikan Keindonesian. Yogyakarta. Arriz media

Kementerian Kesehatan. 2009. Laporan

Hasil Penelitian. Jakarta.

Kemerntrian Kesehatan.

Kompas.com. Rendahnya Minat Baca Anak Indonesia. Akases 24 September 2015.

Menteri Negara Pemberdayaan Perempuan. 2002. Perdagangan Anak Perempuan di beberapa kota.

Melani, Rita, dkk. 2014. "Peran Ilo Melalui Proyek East Dalam Upaya Pencegahan Pekerja Anak Di Indonesia". Jurnal Hubungan Internasional Vol 1, No 2. Unud. Bali.

Nitisastro, Widjojo. 2010. Esai dari 27 Negara Tentang Widjoyo Nitisastro. Jakarta. Kompas.

Rizzana.dkk. 2014. "Analisis Kebijakan Perlindungan Anak Jalanan Dalam Rangka Pengentasan Dari Segala Bentuk Eksploitasi (Studi pada Dinas Sosial Kota.

Malang dan Lembaga Pemberdayaan Anak Jalanan Griya Baca)”. Jurnal Administrasi Publik JAP), Vol.1 No.3. Univ Brawijaya. Malang.

Tempo.com. Kekerasan terhadap Anak. Akses 24 September 2015. 